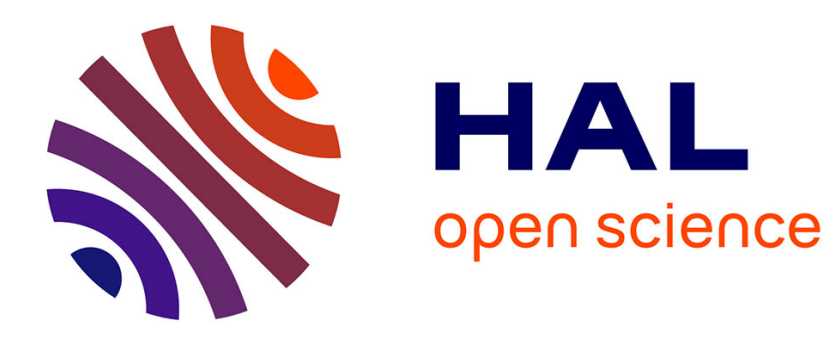

\title{
Evapotranspiration computed by Darcy?s Law: Sudan case study
}

O. A. E. Abdalla

\section{To cite this version:}

O. A. E. Abdalla. Evapotranspiration computed by Darcy?s Law: Sudan case study. Hydrology and Earth System Sciences Discussions, 2005, 2 (4), pp.1787-1806. hal-00298700

\section{HAL Id: hal-00298700 https://hal.science/hal-00298700}

Submitted on 31 Aug 2005

HAL is a multi-disciplinary open access archive for the deposit and dissemination of scientific research documents, whether they are published or not. The documents may come from teaching and research institutions in France or abroad, or from public or private research centers.
L'archive ouverte pluridisciplinaire HAL, est destinée au dépôt et à la diffusion de documents scientifiques de niveau recherche, publiés ou non, émanant des établissements d'enseignement et de recherche français ou étrangers, des laboratoires publics ou privés. 
Hydrol. Earth Sys. Sci. Discuss., 2, 1787-1806, 2005

www.copernicus.org/EGU/hess/hessd/2/1787/

Hydrology and

Papers published in Hydrology and Earth System Sciences Discussions are under open-access review for the journal Hydrology and Earth System Sciences

\section{Evapotranspiration computed by Darcy's Law: Sudan case study}

\section{HESSD}

2, 1787-1806, 2005

\section{Evapotranspiration computed by Darcy's \\ Law}

O. A. E. Abdalla

\section{Title Page}

Abstract

Conclusions

Tables

\section{4}

4

Back
Introduction

References

Figures

$>1$

$>$

Close

Received: 26 July 2005 - Accepted: 19 August 2005 - Published: 31 August 2005

Correspondence to: O. A. E. Abdalla (osman@squ.edu.om)

Full Screen / Esc

(C) 2005 Author(s). This work is licensed under a Creative Commons License. 


\section{Abstract}

The present study applies Darcy's Law to compute evapotranspiration in the arid to semi-arid central Sudan. The average decline in groundwater level $(s)$ along a distance $(L)$ of the aquifer's cross section was calculated. Such decline is a function of 5 discharge $Q$ at any point across the unit width of the aquifer and effective porosity. Groundwater in the study area generally flows from NW to the SE along basin axial trough and is characterized by variable hydraulic gradient. As the aquifer discharge is directly proportional to the gradient, different values of groundwater level decline were calculated along the flow direction.

The hydrogeological map constructed during this study indicates that the system is hydrologicaly closed and groundwater doesn't discharge in the neighboring White Nile River. Geological, hydrological and climatological settings of the discharge area demonstrate that evapotranspiration is the main mechanism of groundwater discharge and reveals that the area is suited for the application of Darcy's Law to compute evapotranspiration.

Evapotranspiration was estimated from Darcy's law to be $1.2 \mathrm{~mm} / \mathrm{a}$ and is sufficient to balance the present system. Greater similarity in geology, hydrology, climate and vegetation encourages the application of Darcy's Law in the Sahara and sub-Sahara to compute for evapotranspiration. Such cost effective method can be applied in arid to semi-arid areas if conditions are favorable.

\section{Introduction}

Evapotranspiration is the primary ground water discharge mechanism that seems to be of vital importance in arid to semi-arid areas as it appeared to have played a major role in ground water depletion in the Saharan and sub-Saharan Africa including Sudan (Kontny, 1993; Heinl et al., 1993; Abdalla, 2000). Central Sudanese Rift Basins cover almost half of Sudan and extend from the arid and semi-arid areas to equatorial
HESSD

2, 1787-1806, 2005

\section{Evapotranspiration computed by Darcy's Law}

O. A. E. Abdalla

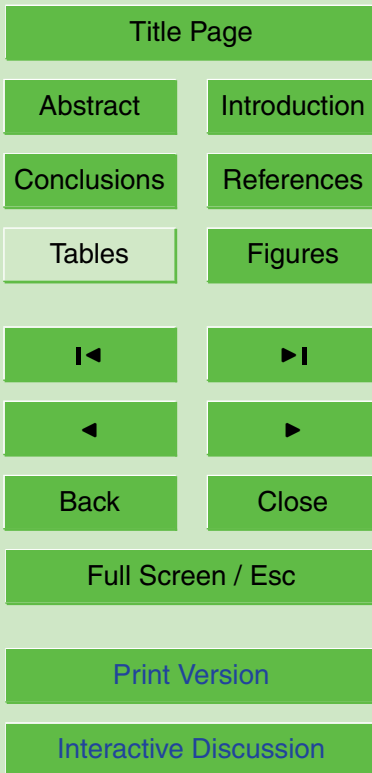

EGU 
regions and they represent one of the vast arenas in which ground water discharge takes place through evapotranspiration (EL Tohami, 1978; Heinl et al., 1993; Salama, 1997; Abdalla, 2000). These rift basins exhibit closed hydrologic systems in which ground water flow eventually forms hydraulic head closures lower than the head in the 5 neighboring surface water bodies. Such hydrogeological setting eliminates the likelihood that the hydraulic gradient is of a residual (paleo) nature. Therefore, it can be concluded that ground water discharge is limited to evapotranspiration. There exist high concentrations of Acacia species, which are the dominant trees in those areas, and also the increase of salinity characterizes areas of discharge (Salama, 1997; Ab10 dalla, 2000). The precise determination of the ground water uptake by plants is a long-term study that requires financial support beyond the capabilities of the African Countries. Methods estimating and evaluating the uptake of ground water from trees have been developed and implemented but are expensive (Hatton et al., 1990; Farrington et al., 1989, 1992, 1994; Salama et al., 1997). As a consequence of financial 15 constraints cheaper, though less precise, methods have to be developed to enhance such estimation in African Countries. Hence, this paper applies Darcy's Law and aims at determining the evapotranspiration value in a selected part of Central Sudanese Rift System. The selected area is bounded by longitudes $30^{\circ} 00^{\prime} \mathrm{E}$ and $32^{\circ} 30^{\prime} \mathrm{E}$, and latitudes $12^{\circ} 30^{\prime} \mathrm{N}$ and $14^{\circ} 15^{\prime} \mathrm{N}$ and lies in west-central Sudan (Fig. 1) and extends west of the White Nile covering an area of approximately $60000 \mathrm{~km}^{2}$ (Fig. 1).

\section{Geology and hydrogeology}

The study area encompasses the Bara and Kosti Basins and is characterized by variable sedimentary thickness that sometimes exceeds $3000 \mathrm{~m}$. These basins are elongated NW-SE and are bounded by deep faults. They represent the most northern extensions of the White and Blue Nile Rift Systems (Fig. 1). The geological succession varies between late Jurassic-Early Cretaceous to Recent sediments (Fig. 2).

The Late Tertiary-Pleistocene fluviatile sediments, referred to as the Umm Rawaba

\section{Evapotranspiration computed by Darcy's Law}

O. A. E. Abdalla

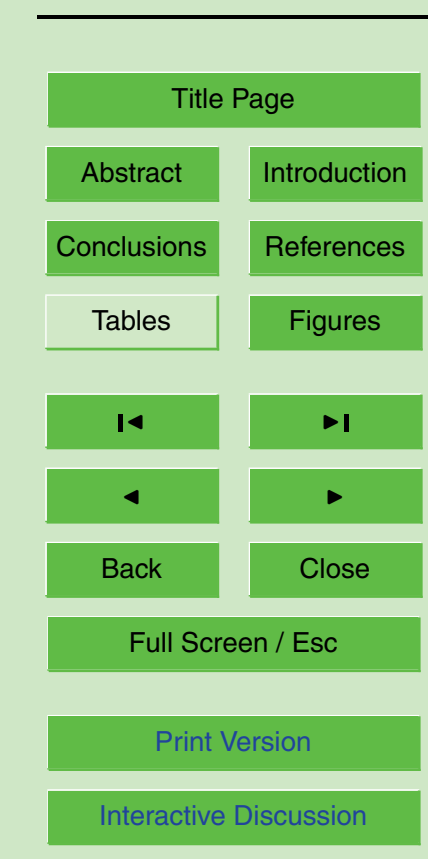

EGU 
Formation form the main aquifer system. This aquifer lies under semi-confining conditions and is separated from the overlying sand dunes by a clay-rich layer that varies in thickness and clay content. The hydraulic conductivity shows considerable variation within the aquifer. However, it averages for $6.8 \times 10^{-6} \mathrm{~m} / \mathrm{s}$ while the storage coefficient 5 is found to be $1.7 \times 10^{-4}$. The mean aquifer thickness is $150 \mathrm{~m}$. Ground water generally flows along the axial trough of the Bara and Kosti Basins from the Northwest to the Southeast and is characterized by variable hydraulic gradient. The hydraulic gradient is steeper in the North and becomes less steep towards the South. Ground water velocities are decreasing southward and amount to few meters per year.

10 The hydrologic system in the study area was saturated 1500-2000 years B.P. when the last humid period that occurred in the area had terminated (Adamson et al., 1980). The present arid conditions have then followed and resulted in a continuous ground water depletion that caused the deepening of the static water level, which ranges between 10 to $100 \mathrm{~m}$ below ground surface (bgs). The depth to the water level is shallower in the 15 Northwest at Kheiran area and deeper towards the South. Steady state flow conditions have been currently reached as indicated by the ground water flow simulation carried out by Abdalla (2000).

The climate is a semi-arid with rainfall ranges between $200 \mathrm{~mm} / \mathrm{a}$ in the North to $450 \mathrm{~mm} / \mathrm{a}$ in the South. Temperature varies between $46^{\circ} \mathrm{C}$ in the summer to $10^{\circ} \mathrm{C}$ in the winter and averages $27^{\circ} \mathrm{C}$.

\section{Theory and discussion}

The hydrogeological map of the study area (Fig. 3) has been prepared after execution of a field study of the area. The map reveals that ground water flow is taking place along and parallel to the main axial troughs of the Bara and Kosti Basins forming two major flow components. In the Bara Basin, it flows from the extreme northwestern part (the Kheiran area west of Bara) towards the SE and ESE. It also flows from the extreme northwestern part of the Kosti Basin to the South and Southeast.

HESSD

2, 1787-1806, 2005

\section{Evapotranspiration computed by Darcy's Law}

O. A. E. Abdalla

\section{Title Page}

Abstract Introduction

Conclusions References

Tables Figures

14

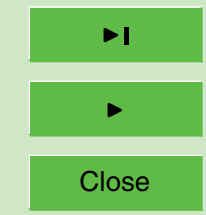

Back

Full Screen / Esc

Print Version

Interactive Discussion

EGU 
The highest hydraulic head is recorded at the Kheiran $(480 \mathrm{~m})$, whereas the lowest $(345 \mathrm{~m})$ is found at the most southeastern part and is enclosed by a circular $350 \mathrm{~m}$ ground water contour line, which forms a hydrologic trough that is elongated parallel to the White Nile (Fig. 4). The ground water flow terminates at this trough and no 5 further flow to the South could be recorded. This closure marks the area of ground water discharge that most probably takes place by evapotranspiration. The topographical elevations in this area average $390 \mathrm{~m}$ a.s.l., which makes a total difference of $40 \mathrm{~m}$ from the static water level (water table surface is $350 \mathrm{~m}$ ). This $40 \mathrm{~m}$ difference represents the average depth to the static water level. Should evapotranspiration be capa10 ble of pumping water from this great depth, a low value of absolute evapotranspiration is more likely. Ground water discharge by evapotranspiration seems to be active at depths greater than $30 \mathrm{~m}$, which is previously suggested by some authors (Vrbka, 1996; Kontny, 1993). Christman et al. (1987) explained that evaporation could reach depths of up to $100 \mathrm{~m}$ but with less effectiveness.

15 The study area is covered by different species of Acacia, whose roots are known to go deep and in some occasions exceed $60 \mathrm{~m}$ (Canadell et al., 1996; De Vries et al., 2000). Depending on the availability of water, these trees can therefore take their demand from the unsaturated and/or saturated zone as they are characterized by both shallow and deep rooting systems. The deep roots will stay immediately above the water level as trees die if they reach the static water level. They receive their water supply from the saturated deep zone through the uprising of ground water into the vadose zone by the capillary fringes.

In reality, the area of the hydrologic trough is characterized by relatively higher rainfall $(450 \mathrm{~mm} / \mathrm{a})$ and more clayey soil compared to the northern part. That is to say, water from the unsaturated zone is available for trees during humid months that occur from July to September. Nevertheless, the high value of potential evapotranspiration $(2500 \mathrm{~mm} / \mathrm{a})$ in addition to a long dry period (October-June) do not allow for water storage within the soil to supply the trees for the whole year. Therefore, trees will take their water demand from the saturated zone during drought, which takes place yearly

HESSD

2, 1787-1806, 2005

\section{Evapotranspiration computed by Darcy's Law}

O. A. E. Abdalla

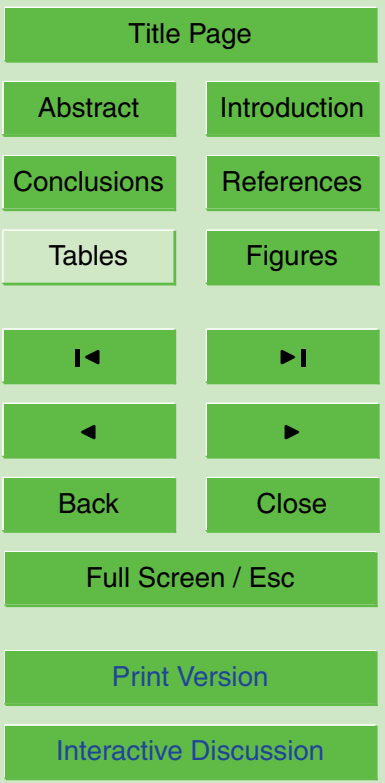

EGU 
in some months, and during some infrequent years every few decades.

The general NW-SE ground water flow in the area is characterized by different hydraulic gradient along both basins. The gradient is steep, moderate and gentle in the Northwest, Central and South and Southeast respectively (Fig. 3). Three different hy5 draulic gradients are recorded in the Kosti, while four are encountered in the Bara Basin. This variation in the hydraulic gradient enabled the subdivision of the system into different hydraulic zones shown in Fig. 3. Bara Basin has been subdivided into four zones named: zone 1, zone 2, zone 3, and zone 4; while Kosti Basin is subdivided into three zones called zone a, zone b, and zone c (Fig. 3). In the Kosti Basin ground water 10 flows from the NW to the SE along the basin axis up to the area of Khor Abu Habil, where it flows to the South to join the flow from the Bara Basin at point $s_{3}$, at the center of the hydrologic trough. The hydraulic head inside this trough is always below $350 \mathrm{~m}$.

The flow along the axial troughs of both basins is illustrated in Figs. 5 and 6, which are hydrogeological cross sections along the axial troughs of the Bara and Kosti Basin 15 respectively. The total length of the flow amounts to about 333 and $242 \mathrm{~km}$. for the Bara and Kosti Basin respectively, while the length of the flow in each zone is denoted by capital letter $L$ (Figs. 5 and 6 ). Due to the variation in the hydraulic gradient, the estimation of the discharge and decline in the groundwater level was carried out for each zone independently. Each zone represents an independent hydrologic system in which recharge occurs as subsurface inflow from the previous zone and discharge takes place as subsurface outflow to the next zone and as evapotranspiration as well. Evapotranspiration is assumed to contribute to the discharge mechanism in each zone independently. The subsurface natural discharge and the evapotranspiration causes drop in the static water level which leads to the deepening of that level to reach sometimes $100 \mathrm{~m}$ bgs in some areas. This static water level deepening has been taking place for long time (1500-2000 year B.P.). It is an exponential drop that is reduced with time till the hydrologic system achieves the steady state conditions whereby inflow and outflow are equal. The discharge mechanisms that might have been previously prevailing (mainly natural discharge into the White Nile) are now limited to evapotranspiration
HESSD

2, 1787-1806, 2005

\section{Evapotranspiration computed by Darcy's Law}

O. A. E. Abdalla

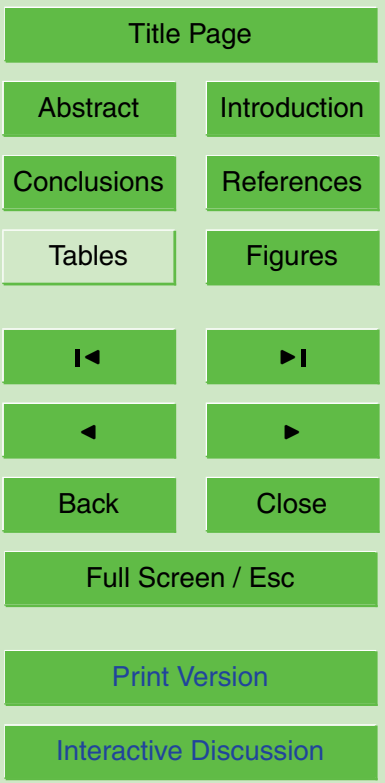

EGU 
and natural subsurface outflow. The effect of the present artificial discharge is almost negligilble, as the total volume of extracted water does not exceed $2 \times 10^{5} \mathrm{~m}^{3} /$ day and is concentrated in the northern part (Abdalla, 2000). The number of boreholes drilled in the southeast is very limited as the ground water is saline and there is adequate 5 surface water supply. Hence, the amount of the present ground water discharge is reduced compared to the past and therefore the expected decline in the static water level is minimum. The current decline in the groundwater level consequent to the natural discharge could be computed from Darcy's law under the following assumptions:

- Ground water flow is unidirectional. That is to say, ground water flows only along and parallel to the cross section (Figs. 5 and 6). The ground water flow direction in the study area shows reasonable parallelism indicated by Fig. 3.

- No ground water recharge is taking place from direct infiltration. The rainfall in the study area ranges between 200 to $450 \mathrm{~mm} / \mathrm{a}$ and is restricted to 3 months in the year (Summer time). Direct infiltration of rainwater into the aquifer at the area of the hydrologic trough is unlikely as the static water is deeper $(40 \mathrm{~m})$, the soil is clayey and the daily temperature during rainy season is higher. Recharge occurs only along the northern edge of the basins subsequent to storm events and through drainage basins disappearing beneath the sand dunes in the northern part (Abdalla, 2000).

According to Darcy's law, the constant discharge $Q$ at any point across the aquifer of unit width equals:

$Q=K . I . b$,

where, $b$ represents the thickness of the aquifer, $K$ is the hydraulic conductivity and $I$ is the gradient.

25 The average decline in groundwater level $(s)$ along a distance $L$ of unit width of the aquifer cross sections (Figs. 5 and 6 ) can be calculated:

$s=Q / n_{e} \cdot L=K \cdot I \cdot b / n_{e} \cdot L$,

HESSD

2, 1787-1806, 2005
Evapotranspiration

computed by Darcy's

Law

O. A. E. Abdalla

\section{Title Page}

Abstract Introduction

Conclusions References

Tables Figures

14

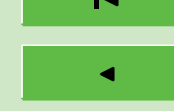

$\rightarrow$

Back

Close

Full Screen / Esc

Print Version

Interactive Discussion 
where, $n_{e}$ is the effective porosity.

The hydraulic gradient $(I)$ is calculated from the hydrogeological map (Fig. 3) for all zones to be $I_{1}=3.0 \times 10^{-3}, I_{2}=8.4 \times 10^{-4}, I_{3}=1.4 \times 10^{-4}, I_{4}=1.0 \times 10^{-4}, I_{a}=3.6 \times 10^{-4}$, HESSD $I_{b}=1.4 \times 10^{-4}$ and $I_{c}=7 \times 10^{-4}$.

5 Aquifer's thickness examined during this study from the borehole data of over 500 wells is in agreement with the previous hydrogeological investigations conducted in the area (Geotehnika, 1985, 1988; IFAD, 1993; Rodis et al., 1965; Abdalla, 2000) which assumed $150 \mathrm{~m}$ as an average thickness of the aquifer although some variations are observed. This average thickness value is apparently true in the whole area except west of Kosti (at zone 4) where drilling showed that aquifer thickness averages only $70 \mathrm{~m}$.

The effective porosity of the deep aquifer could not be determined during this study as no core samples were available. The average effective porosity value (10\%) that has been implemented in the following calculations is based mainly on previous estimations 15 cited in Abdel Salam, 1966; El Boushi et al., 1982; El Tohami, 1978; Thorweihe, 1982; Heinl et al., 1993; Kheir, 1986; Vrbka, 1996; and Abdalla, 2000.

The hydraulic conductivity $(K)$ varies significantly from one zone to another. It has been calculated during this study from several pumping tests available in the database of the Natural Corporation of Rural Water Development (NCRWD). Representative mean hydraulic conductivity, is estimated to be $4.0 \times 10^{-5} \mathrm{~m} / \mathrm{s}$ for zone $1,1.5 \times 10^{-6} \mathrm{~m} / \mathrm{s}$ for zones 2 and 3 , and $1.0 \times 10^{-5} \mathrm{~m} / \mathrm{s}$ for zone 4 , while it is estimated to be $8.0 \times 10^{-7} \mathrm{~m} / \mathrm{s}$ for zones $a$ and $b$, and $1.5 \times 10^{-6} \mathrm{~m} / \mathrm{s}$ for zone $c$.

Based on the above mentioned values for $I, K$ and $n_{e}$ the amount of the subsurface flow $(Q)$ and decline in groundwater $(s)$ along each zone is calculated, first for the Bara Basin and next for Kosti Basin, according to Eqs. (1) and (2).

\section{Evapotranspiration computed by Darcy's Law}

O. A. E. Abdalla

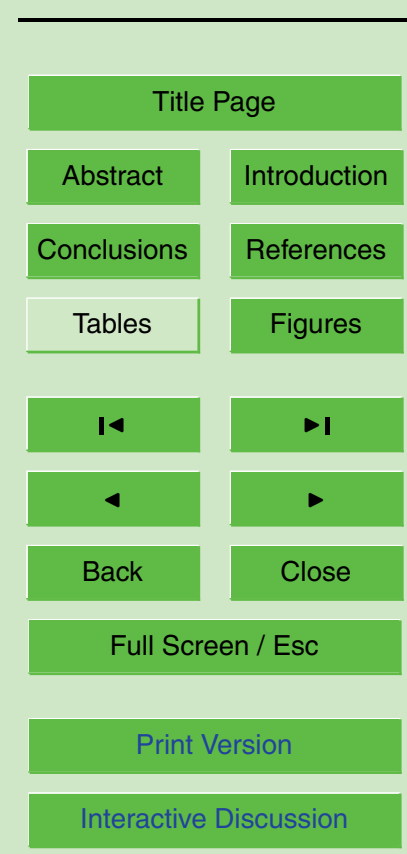

EGU 


\subsection{Bara Basin}

The amount of the flow $(Q)$ along the different zones in Bara Basin was found to be:

$Q_{1}=3.0 \times 10^{-3} \times 4.0 \times 10^{-4} \times 150=1.8 \times 10^{-5} \mathrm{~m}^{3} / \mathrm{s}=1.56 \mathrm{~m}^{2} /$ day

$Q_{2}=8.4 \times 10^{-4} \times 1.5 \times 10^{-6} \times 150=1.9 \times 10^{-7} \mathrm{~m}^{3} / \mathrm{s}=1.6 \times 10^{-2} \mathrm{~m}^{2} /$ day

${ }_{5} Q_{3}=1.4 \times 10^{-4} \times 1.5 \times 10^{-6} \times 150=3.2 \times 10^{-8} \mathrm{~m}^{3} / \mathrm{s}=2.7 \times 10^{-3} \mathrm{~m}^{2} /$ day

$Q_{4}=1.0 \times 10^{-4} \times 4.0 \times 10^{-5} \times 70=2.8 \times 10^{-7} \mathrm{~m}^{3} / \mathrm{s}=2.4 \times 10^{-2} \mathrm{~m}^{2} /$ day

The values $Q_{1}, Q_{2}$ and $Q_{3}$ represent the subsurface outflow from the aquifer, while $Q_{4}$ represents the subsurface inflow from the White Nile into the aquifer (Fig. 3).

The length of the flow along the different zones in the Bara Basin is found to be: $10 L_{1}=52.6 \mathrm{~km}, L_{2}=96.1 \mathrm{~km}, L_{3}=118.4 \mathrm{~km}$ and $L_{4}=66 \mathrm{~km}$. Hence, the average decline in groundwater level $s$ has been calculated on the basis of Eq. (2) to be:

$s_{1}=1.56 /\left(0.1 \times 52.6 \times 10^{3}\right)=2.97 \cdot 10^{-4} \mathrm{~m} /$ day $=108.3 \mathrm{~mm} / \mathrm{a}$

$s_{2}=1.6 \times 10^{-2} /\left(0.1 \times 96.1 \times 10^{3}\right)=1.67 \times 10^{-6} \mathrm{~m} /$ day $=0.608 \mathrm{~mm} / \mathrm{a}$

$s_{3}=2.7 \times 10^{-3} /\left(0.1 \times 118.4 \times 10^{3}\right)=2.30 \times 10^{-7} \mathrm{~m} /$ day $=0.083 \mathrm{~mm} / \mathrm{a}$

${ }_{15} s_{4}=2.4 \times 10^{-2} /\left(0.1 \times 66.0 \times 10^{3}\right)=3.67 \times 10^{-6} \mathrm{~m} /$ day $=1.330 \mathrm{~mm} / \mathrm{a}$

The average groundwater decline in zone 4 represents a residual decline whereby water level rises along a distance $L_{4}(66 \mathrm{~km})$ instead of falling. This is because $Q_{4}$ represents an inflow from the White Nile rather than outflow from the hydrologic system. Thus, at the point $s_{3}$ (Fig. 3) where zones 3 and 4 terminate, ground water surplus is indicated (as $1.33-0.083=1.247 \mathrm{~mm} / \mathrm{a}$ ). This is valid under the condition that no other means of ground water discharge will occur. However, point $s_{3}$ lies in the center of
HESSD

2, 1787-1806, 2005

Evapotranspiration

computed by Darcy's

Law

O. A. E. Abdalla

Title Page

Abstract

Introduction

Conclusions

References

Tables

Figures

14

4

Back 
the hydrologic trough where the main ground water discharge by evapotranspiration seems to take place. But the system is known to be under equilibrium conditions (Abdalla, 2000), which indicates that the $1.25 \mathrm{~mm} / \mathrm{a}$ could be the possible amount of evapotranspiration in the specified area to balance the system if ground water flow from 5 Kosti Basin is neglected.

\subsection{Kosti Basin}

On the basis of Eqs. (1) and (2) the groundwater discharge $(Q)$ and level decline $(s)$, have been calculated from the cross section in Fig. 6 for the Kosti Basin provided that the length of flow along zone a, b, and c corresponds to 97,75 , and $70 \mathrm{~km}$, respectively:

$Q_{a}=3.6 \times 10^{-4} \times 8 \times 10^{-7} \times 150=3.7 \times 10^{-3} \mathrm{~m}^{2} /$ day

$Q_{b}=1.4 \times 10^{-4} \times 8 \times 10^{-7} \times 150=1.5 \times 10^{-3} \mathrm{~m}^{2} /$ day

$Q_{C}=7 \times 10^{-5} \times 1.5 \times 10^{-6} \times 150=1.4 \times 10^{-3} \mathrm{~m}^{2} /$ day

$s_{a}=4.3 \times 10^{-8} /\left(0.1 \times 97 \times 10^{3}\right)=4.4 \times 10^{-12} \mathrm{~m} / \mathrm{s}=0.140 \mathrm{~mm} / \mathrm{a}$

$s_{b}=1.7 \times 10^{-8} /\left(0.1 \times 75 \times 10^{3}\right)=2.3 \times 10^{-12} \mathrm{~m} / \mathrm{s}=0.073 \mathrm{~mm} / \mathrm{a}$

$15 s_{C}=1.6 \times 10^{-8} /\left(0.1 \times 70 \times 10^{3}\right)=2.3 \times 10^{-12} \mathrm{~m} / \mathrm{s}=0.073 \mathrm{~mm} / \mathrm{a}$

The evapotranspiration seems to be active in the whole area with emphasis on the area of the hydrologic trough. The absolute amount of the evapotranspiration $(E)$ at point $s_{3}$ should be in equilibrium with the recharge as subsurface inflow from zones 3,4 and $c$ to achieve the steady state flow conditions. Therefore, the value of evapotranspiration at the hydrologic trough could be estimated from the decline in the groundwater level values obtained in the two cross sections (Figs. 5 and 6). This value was estimated at point $s_{3}$ to be:

$E=1.33-(0.083+0.073)=1.2 \mathrm{~mm} / \mathrm{a}$,

\section{Evapotranspiration computed by Darcy's Law}

O. A. E. Abdalla

\section{Title Page}

Abstract

Introduction

Conclusions

References

Tables

Figures

14

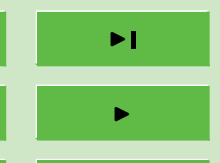

4

Back

Close

Full Screen / Esc

Print Version

Interactive Discussion

EGU 
where the values in brackets are the groundwater declines along zone 3 and zone $c$, while the first value is the expected rise of the water level along zone 4 . This is calculated under the assumption that the flow is taking place only along the cross sections and each zone represents an independent hydrologic system. This value

$5(1.2 \mathrm{~mm} / \mathrm{a})$ could be generalized to indicate the absolute value of evapotranspiration in the study area. It may also indicate the value of the ground water consumption by Acacia trees in the discharge areas around the Central Sudanese Rift Basins.

The application of Darcy's law to estimate absolute evapotranspiration faces some constrains. Unidirectional flows do not commonly occur in the nature as anisotropy 10 is very common in several aquifers. Therefore, the consideration of the general flow direction and assumption of the parallelism of this flow ignores the local flows and produces errors in the calculation of the natural discharge $Q$. Aquifer heterogeneity represents another constrain as it affects the value of the hydraulic conductivity $(K)$. $K$ value should be representative and errors in the estimation of the $K$ result in errors

15 in $S$. The assumption of no recharge is taking place by direct infiltration is valid only in arid to semi-arid areas which restricts the application of this method to those areas. The Saharan and sub-Saharan African countries represent the most suitable areas as geological, hydrological and climatological conditions of those areas are characterized by remarkable regional similarities. The type, density and distribution of vegetation cover on the other hand are quite similar across the region. Those countries are also suffering financial limitations that make relying on the less expensive method of computing evapotranspiration, like the current one, more favored. Nonetheless, in these areas studies on recharge should be taken before the application of this method.

\section{Conclusions}

25 Darcy's law can be used in estimating the absolute evapotranspiration in arid to semiarid areas where no other discharge mechanism is prevailing. This will be successfully achieved if no direct infiltration occurs and the ground water flow is more or less unidi-

HESSD

$2,1787-1806,2005$

\section{Evapotranspiration computed by Darcy's Law}

O. A. E. Abdalla

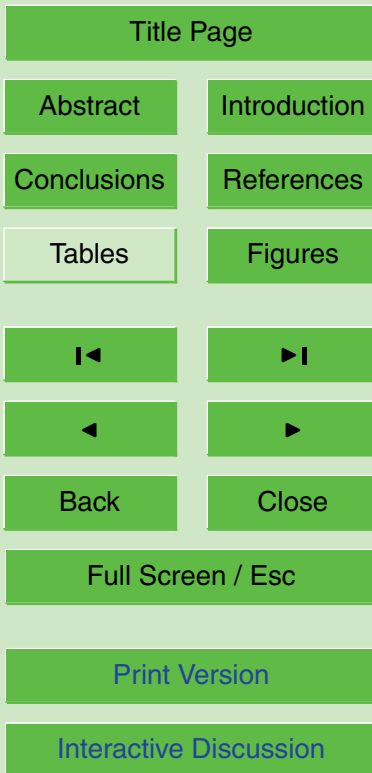

EGU 
rectional.

Acknowledgements. Thanks are due to the German Academic Exchange Services (DAAD) for the financial support all over the period of the study. I am greatly indebted to the NCRWD offices in Khartoum and El Obeid for providing the data and the thorough discussion and motivation.

\section{References}

Abdalla, O. A. E.: Groundwater Hydrology of the west-central Sudan, Verlag Dr. Koster, Berlin Germany, ISBN 3-89574-364-X, 2000.

Abdel Salam, Y.: The ground water geology of the Gezira. M.Sc. thesis, Department of Geology, University of Khartoum, Khartoum, Sudan, 1966.

10 Adamson, D. A., Gasse, F., Street, F. A., and Williams, M. A. J.: Late Quaternary history of the Nile, Nature, 288, 50-55, 1980.

Canadell, J., Jakson, R. B., Ehleringer, J. R., Mooney, H. A., Sala, O. E., and Schulze, E. D.: Maximum rooting depth of vegetation types at the global scale. Oecologia, 108, 583-595, 1996.

De Vries, J. J., Selaolo, E., and Beekman, H. E.: Groundwater recharge in the Kalahari, with reference to paleo-hydrologic conditions, J. Hydrol., 238, 110-123, 2000. 110-123

El Boushi, I. M. and Abdel Salam, Y.: Stratigraphy and ground water geology of the Gezira, in: A land between two Niles, edited by: Williams, M. A. J. and Adamson, D., Rotterdam, Balkema, 65-80, 1982.

20 El Tohami, M. S.: Geology and hydrogeology of Baggara Basin, Sudan, Ph.D. thesis, Department of Geology, London University, London, United Kingdom, 1978.

Farrington, P., Greenwood, E. A. N., Bartel, G. A., Beresford, J. D., and Watson, G. D.: Evaporation from Banksia woodland on a ground water mound, J. Hydrol., 105, 173-186, 1989.

Farrington, P., Watson, G. D., Bartel, G. A., and Greenwood, E. A. N.: Evaporation from dampland vegetation on a ground water mound, J. Hydrol., 115, 65-75, 1990.

Farrington, P., Bartel, G. A., Watson, G. D., and Salama, R. B.: Long term transpiration from two Eucalypt species in a native woodland estimated by the heat pulse technique, Aust. J. Ecol., 5, 224-225, 1994.

Farrington, P., Salama, R. B., Greenwood, E. A. N., and Bartel, G. A.: Water use of agricultural

\section{Evapotranspiration computed by Darcy's Law}

O. A. E. Abdalla

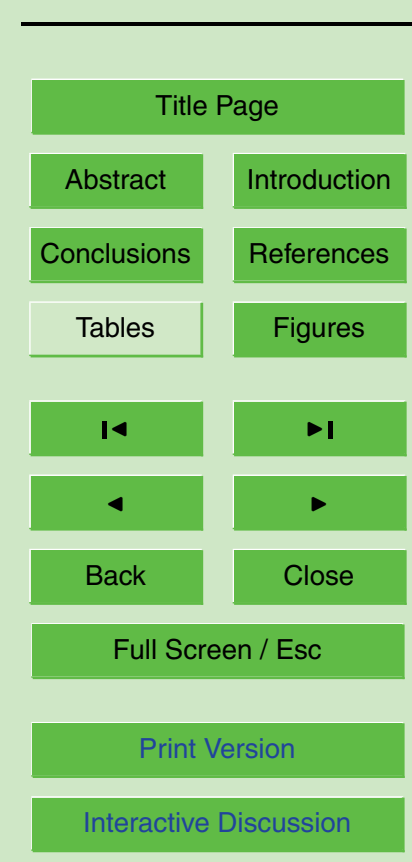

EGU 
and native plants in a Western Australian wheatbelt catchment, Agricultural Water Management, 22, 4, 357-367, 1992.

Geotehnika: El Obeid water supply project, Feasibility study of ground water resources, Master report, National Water Administration, Ministry of Energy and Mining, Khartoum, Sudan, 1985.

Geotehnika: El Obeid water supply project, Exploration of ground water resources, National Corporation for development of rural water resources, Ministry of Irrigation and water resources, Khartoum, Sudan, 1988.

Hatton, T. J. and Vertessy, R. A.: Transpiration of plantation of Pinus radiata estimated by the heat pulse method and Bowen Ratio, J. Hydrol., 4, 289-298, 1990.

Heinl, M. and Thorweihe, U.: Ground water balance of the sedimentary aquifer in Darfur, Upper Nile area, Sudan, in: Geoscientific research in Northeast Africa, Proc. of Intern. Conf. on Geosci. Res., Northeast Africa, edited by: Thorweihe, U. and Schandelmeier, H., Rotterdam, 687-692, 1993.

15 IFAD: Northern Kordofan Rural Development Project, Special Identification Mission Reports, Ministry of Irrigation and water resources, Khartoum, Sudan, 1993.

Kheir, O. M.: Hydrogeology of Dongola area, Northern Sudan, Berl. Geowiss. Abh. (A), 74, 81 p., Berlin, Germany, 1986.

Kontny, J.: Grundwasserverdunstung in ostsaharischen Senkgebieten unter besonderer 20 Berücksichtigung der Transpiration wild wachsender Vegetation, Berl. Geowiss. Abh. (A), 151, 99 p., Berlin, Germany, 1993.

National Corporation of Rural Water Development (NCRWD): Different well reports (unpublished). Ministry of Irrigation, Khartoum, Sudan, 1958-1995.

Rodis, H. G., Hassan, A., and Wahdan, L.: Ground water geology of Kordofan Province, Sudan. 25 Bulletin No. 14, Ministry of Irrigation, Khartoum, Sudan, 1965.

Salama, R. B., Bartle, G. A., and Farrington, P.: Water use of plantation Eucalyptus camaldulensis estimated by ground water hydrograph separation techniques and heat pulse method, J. Hydrol., 156, 163-180, 1997.

Salama, R. B.: African basins, in: Sedimentary basins of the world, edited by: Selly, R. C., 3, 105-1149, Elsevier, 1997.

Thorweihe, U.: Hydrogeologie des Dakhla-Beckens (Ägypten), Berl. Geowiss. Abh., (A), 38, 53 p., Berlin, Germany, 1982.

Vrbka, P.: Hydrogeologische und Isotopenhydrogeolische Untersuchungen zur regionalen

\section{Evapotranspiration computed by Darcy's Law}

O. A. E. Abdalla

\section{Title Page}

\section{Abstract}

Introduction

Conclusions

References

Tables

Figures

14

4

Back

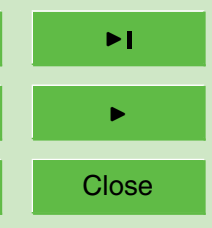

Full Screen / Esc

Print Version

Interactive Discussion 
Problemen der GW-Neubildung, der GW-Zirkulation und des Wasserhaushaltes im Nordsudan, Berl. Geowiss. Abh. (A), 186, 158 p., Berlin, Germany, 1996.

\section{HESSD}

2, 1787-1806, 2005

\section{Evapotranspiration computed by Darcy's Law}

O. A. E. Abdalla

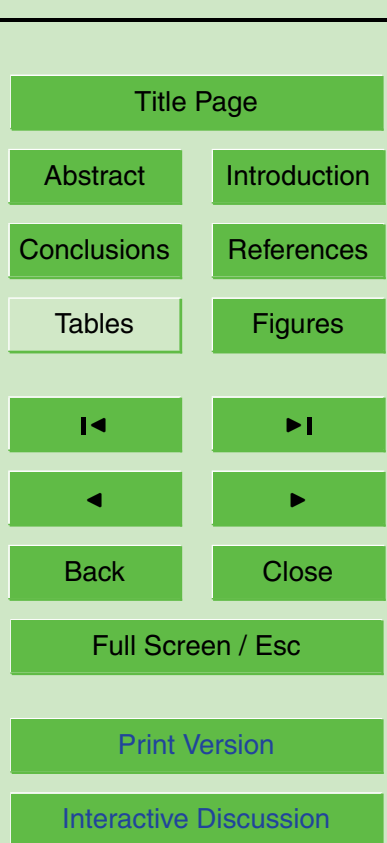




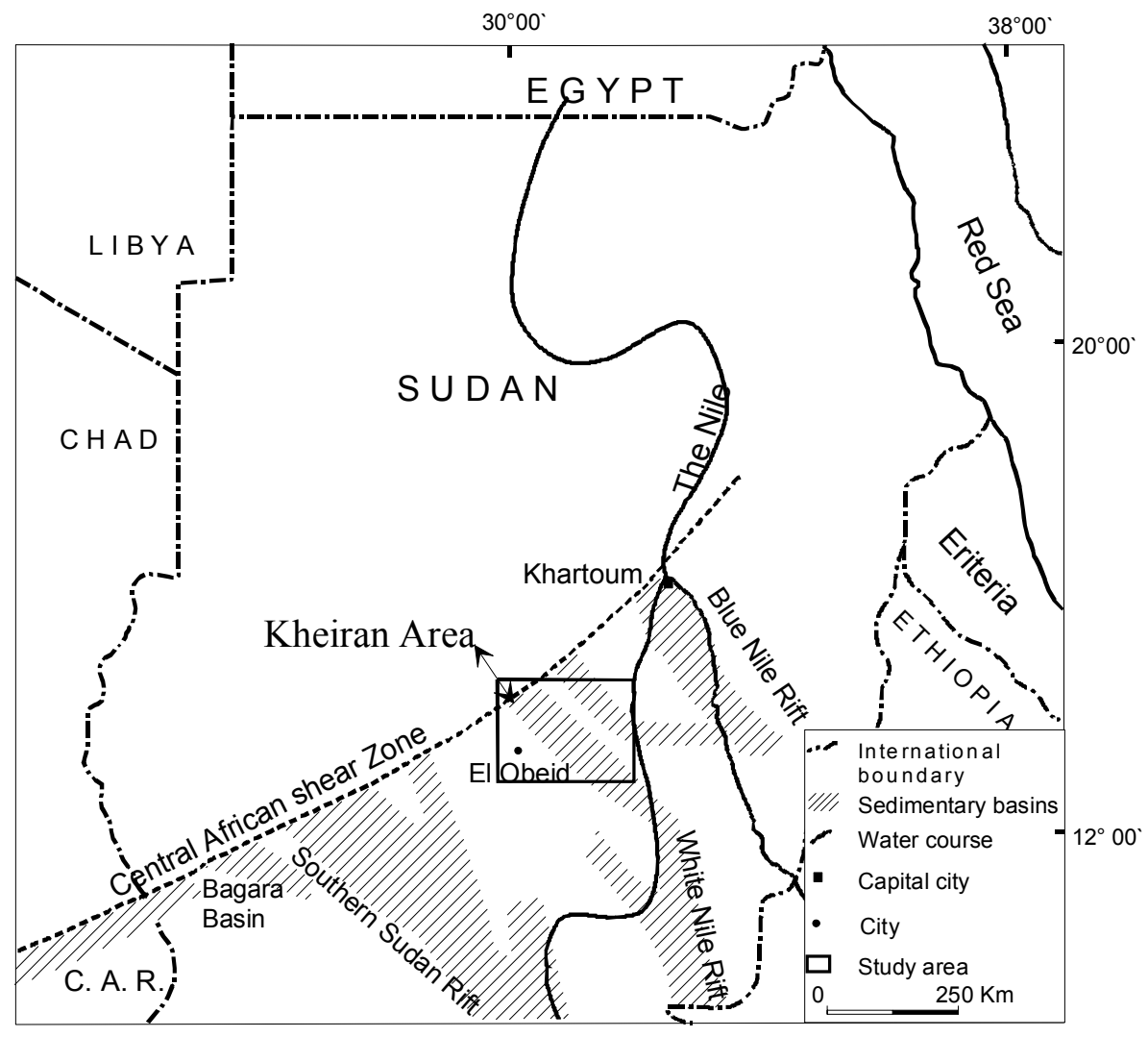

Fig. 1. The location of the study area within the Central Sudan Rift Basins, which are bounded on their north edges by the Central African Shear Zone. The location of the study area is marked by the square.
HESSD

2, 1787-1806, 2005

\section{Evapotranspiration computed by Darcy's Law}

\section{O. A. E. Abdalla}

\section{Title Page}

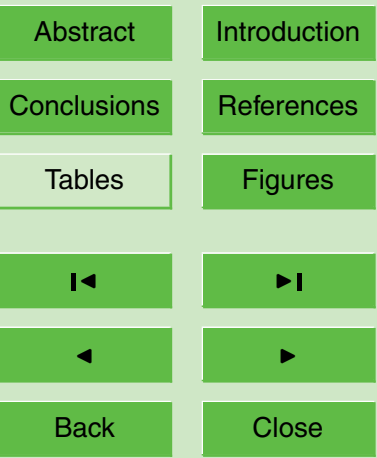

Full Screen / Esc

Print Version

Interactive Discussion 


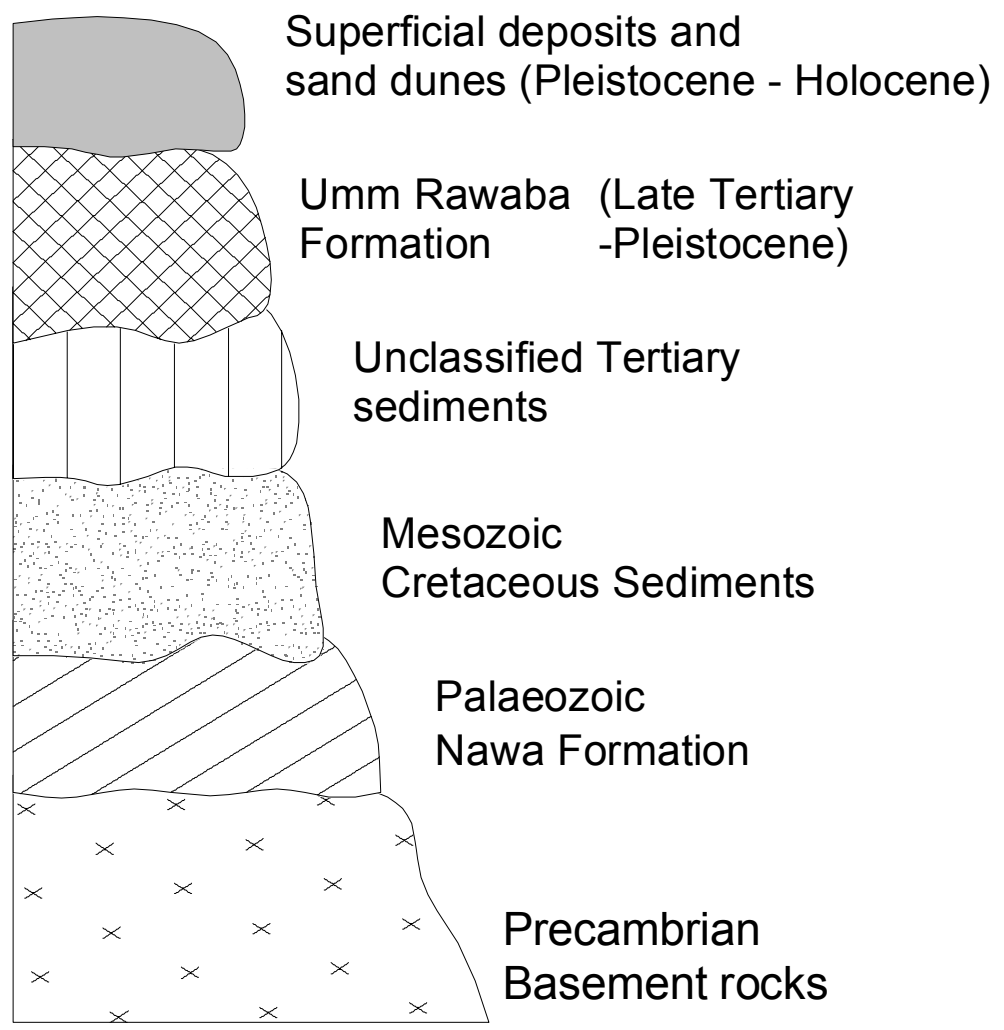

\section{Evapotranspiration computed by Darcy's \\ Law}

O. A. E. Abdalla

Unclassified Tertiary sediments

Title Page

Abstract

Conclusions

Tables

14

4

Back

Full Screen / Esc

Print Version

Fig. 2. Schematic diagram shows the geological succession. 


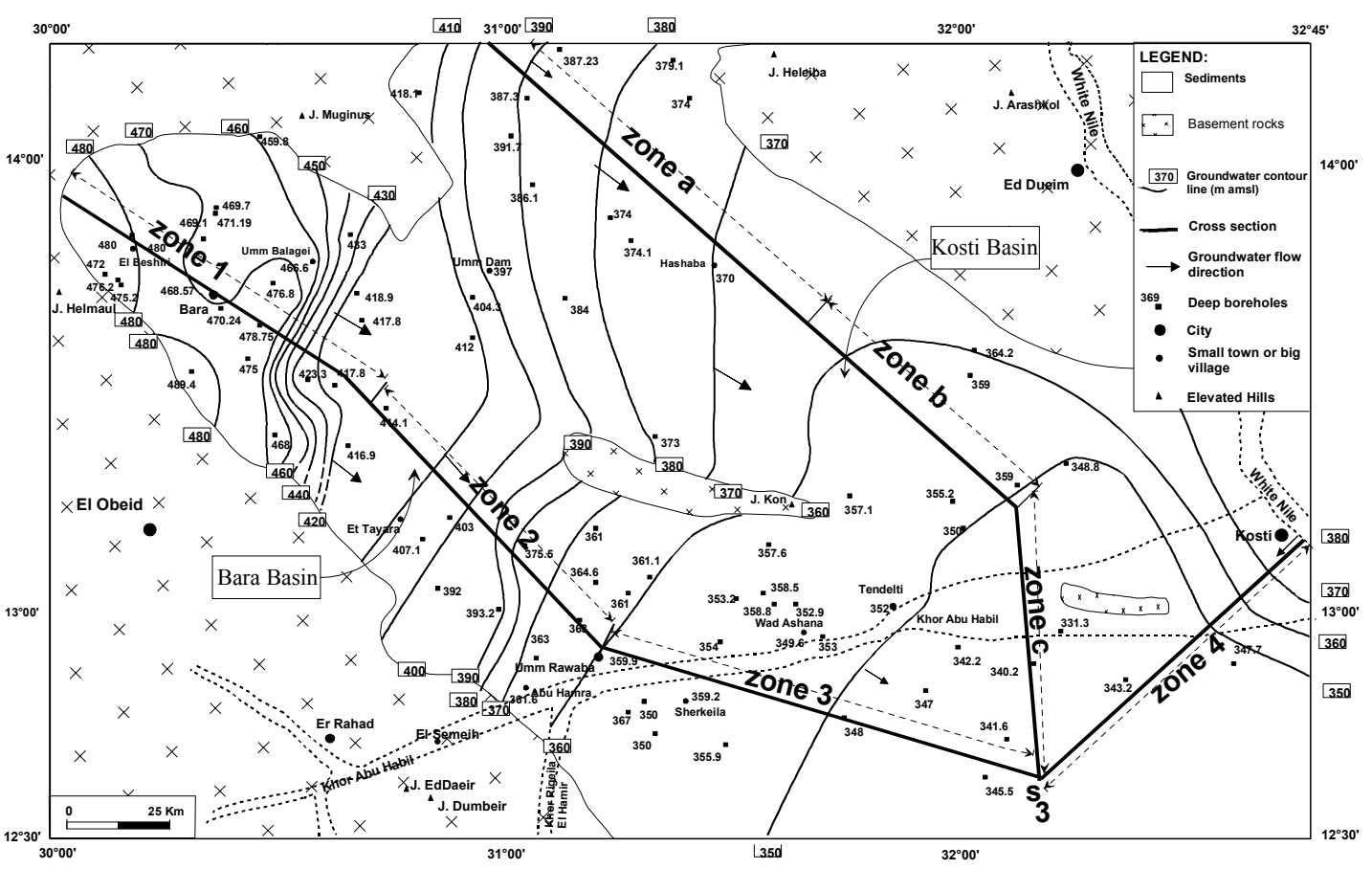

Fig. 3. Hydrogeological map of the study area. Ground water flows generally from the NW to the SE with variable hydraulic gradients. Closed contour lines are recorded east of Bara indicating steeper hydraulic gradient, while widely spaced lines characterize the southeastern part and indicate a gentler gradient. The diagram also illustrates the location of the point $s_{3}$, where evapotranspiration is estimated, and the cross sections, which are plotted in the next Figs. 5 and 6 .
HESSD

2, 1787-1806, 2005

\section{Evapotranspiration computed by Darcy's Law}

\section{O. A. E. Abdalla}

\section{Title Page}

\begin{tabular}{|c|c|}
\hline Abstract & Introduction \\
\hline Conclusions & References \\
\hline Tables & Figures \\
\hline 14 & $\rightarrow 1$ \\
\hline 4 & $\triangleright$ \\
\hline Back & Close \\
\hline
\end{tabular}

\section{Full Screen / Esc}

Print Version

Interactive Discussion 


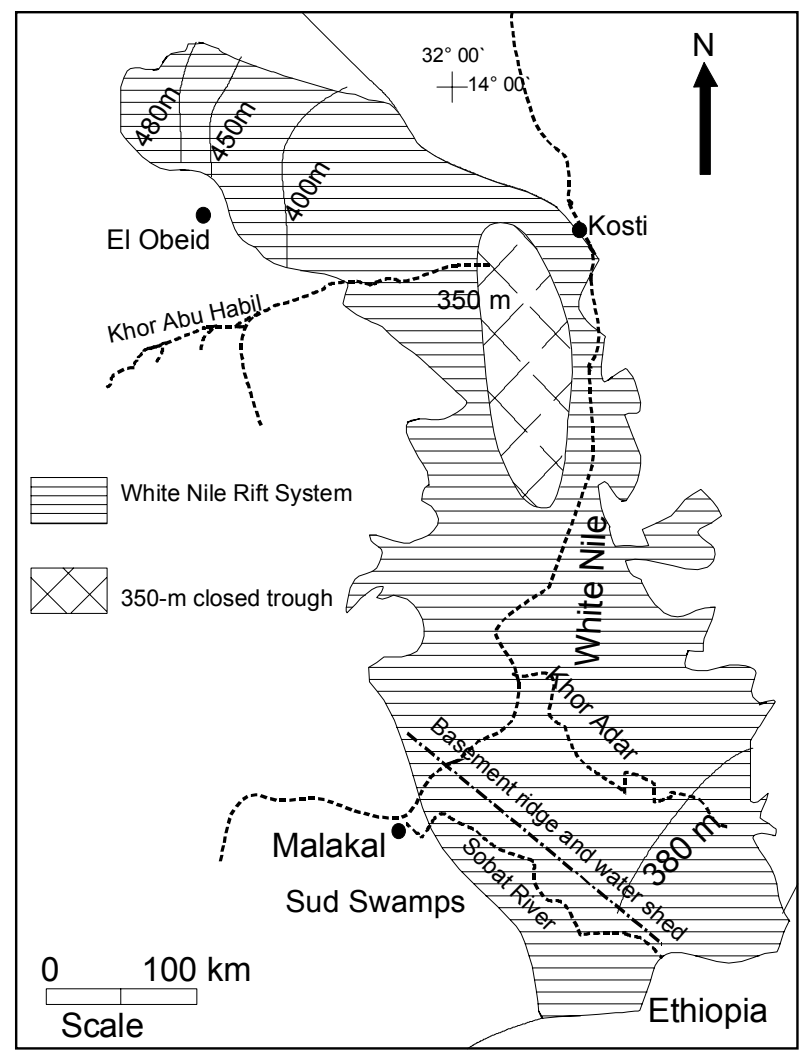

Fig. 4. The hydrogeology of the White Nile Rift System. The diagram shows the location of the closed hydrologic trough, through which discharge mechanism takes place. The study area represents the northern part of the Rift System. Ground water moves from the South and North towards the center of the Rift System.
HESSD

2, 1787-1806, 2005

\section{Evapotranspiration computed by Darcy's Law}

O. A. E. Abdalla

Title Page

\begin{tabular}{|c|c|}
\hline Abstract & Introduction \\
\hline Conclusions & References \\
\hline Tables & Figures \\
\hline 14 & $\rightarrow 1$ \\
\hline 4 & $\triangleright$ \\
\hline Back & Close \\
\hline
\end{tabular}

Full Screen / Esc

Print Version

Interactive Discussion 


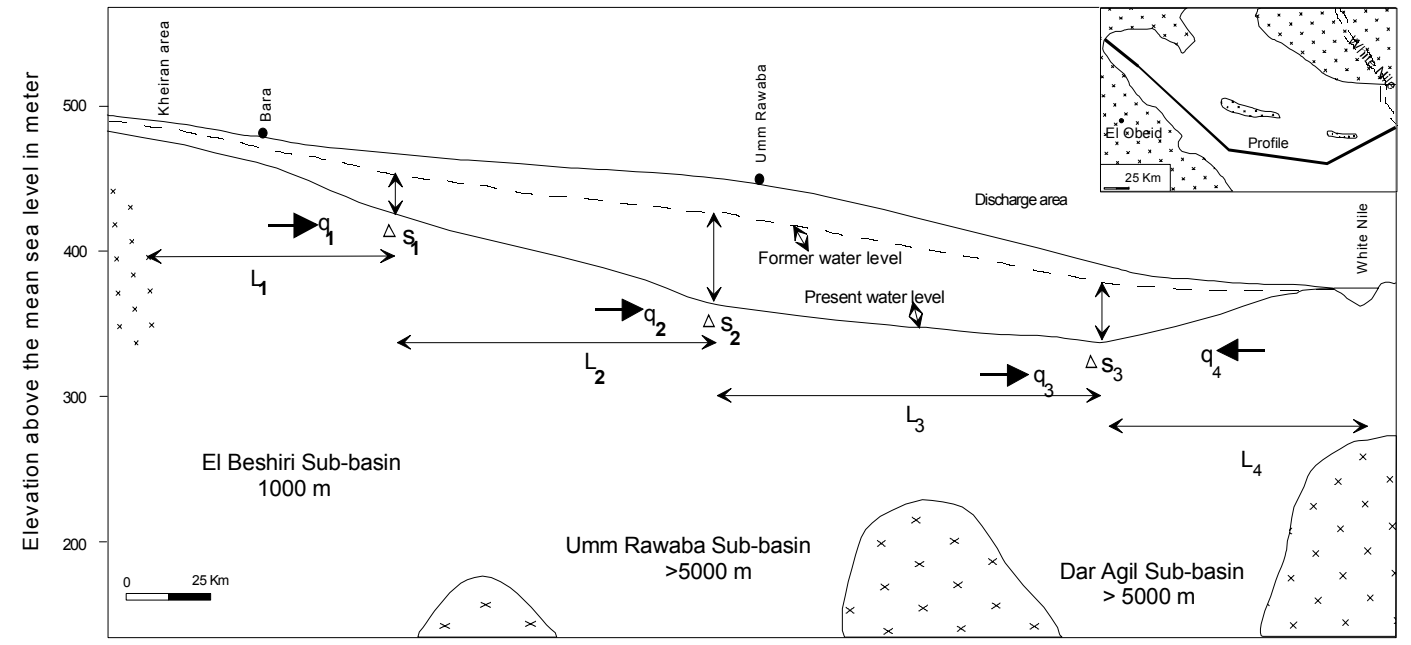

Fig. 5. Cross section illustrates the hydrogeological situation of the deep aquifer along the axial trough of the Bara Basin. The section trends NW-SE, begins at the Kheiran area, and ends at the White Nile. Four different zones of different hydraulic gradients are recorded and the distances of the flow path are marked by capital letter $L$. The total length of the section is about $362 \mathrm{~km}$. The small letter $q$ indicates specific discharge when is multiplied by aquifer thickness $(b)$ yields discharge per quifer unit width $(Q)$ that is used in the calculation.

\section{Evapotranspiration computed by Darcy's Law}
O. A. E. Abdalla

\section{Title Page}

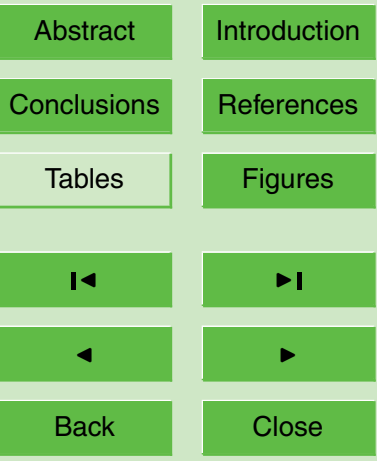

Full Screen / Esc

Print Version

Interactive Discussion 


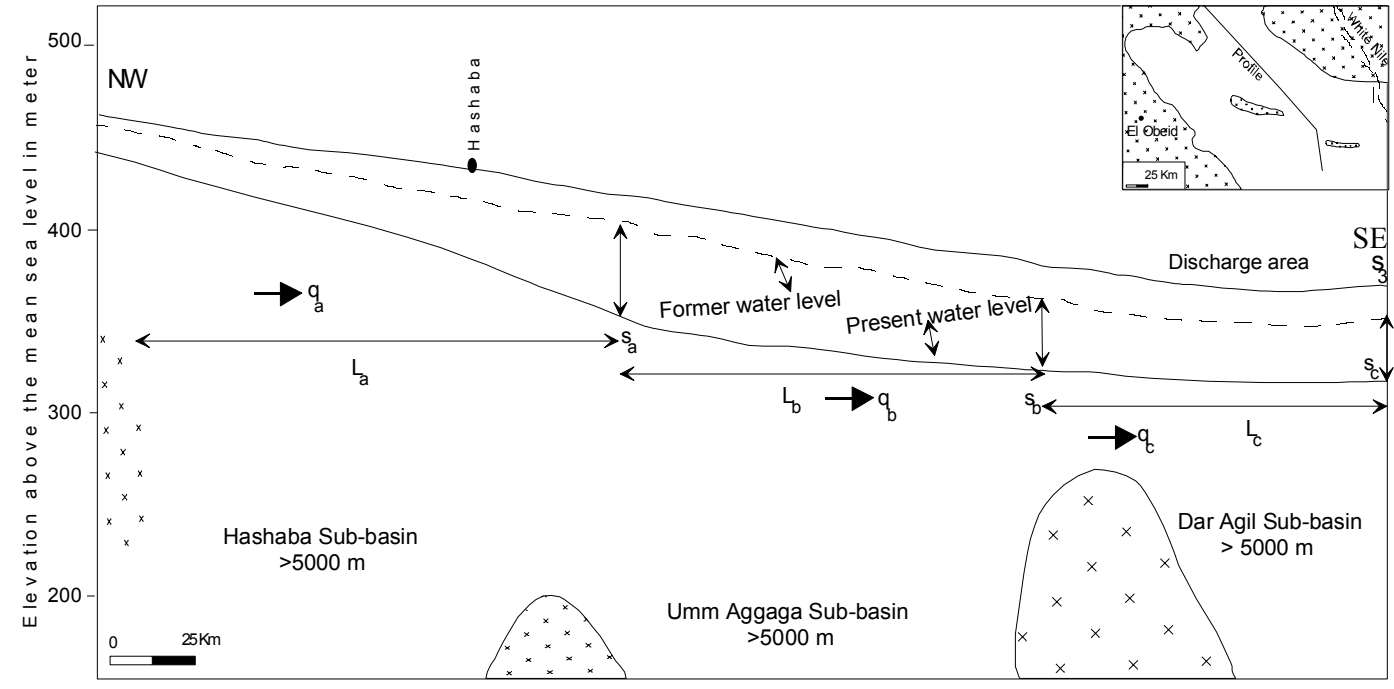

Fig. 6. A cross section along the axial trough of the Kosti Basin. Three different hydraulic zones are identified. The section generally trends NW-SE. It starts at the northwestern part of the Kosti Basin and ends at the White Nile. It covers the hydrologic situation in the basin with a total length of about $229 \mathrm{~km}$.

\section{Evapotranspiration computed by Darcy's Law}

O. A. E. Abdalla

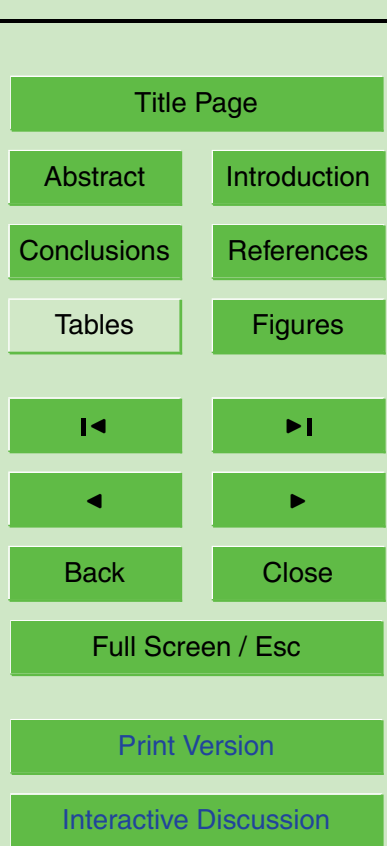

